\title{
Research Paper Effect of auxin concentrations on yield and economics of the crop production of cabbage (Brassica oleracea var. capitata L.)
}

See end of the paper for authors' affiliations

Correspondence to : VIJAY KUMAR Department of Horticulture, College of Horticulture (B.A.U.), Noorsarai, NALANDA (BIHAR) INDIA

Email:

vijaykumar0517@gmail. com

Paper History : Received : 11.09.2014; Revised : 26.01.2015; Accepted : 13.02 .2015
ABSTRACT : An experiment was conducted at experimental field of Narendra Dev University of Agriculture and Technology, Kumarganj Faizabad, U.P. during the year 2011-12, to assess the economic profitability and yield of cabbage through application of various levels of auxins viz., IAA @ 50 ppm, IAA @ 100 ppm, IAA @ 150 ppm, IBA @ 50 ppm, IBA @ 100 ppm, IBA @ 150 ppm on two varieties Golden Acre $\left(\mathrm{V}_{1}\right)$, Pride of India $\left(\mathrm{V}_{2}\right)$. The experiment was planned under Factorial Randomize Block Design. The acceptance of any agricultural recommendation is mainly depending on its benefit: cost ratio. Yield of cabbage (q/ha.), cost of cultivation (Rs./ ha.), gross income (Rs./ha.), net profit (Rs./ha) and benefit : cost ratio were calculated under the various treatments during the experiment. The maximum cabbage head yield $(327.50 \mathrm{q} / \mathrm{ha})$ were obtained with $\mathrm{T}_{6} \mathrm{~V}_{2}$ treatment. Highest net return (116193.24 Rs./ha) and benefit: cost ratio (1:3.74) have been estimated by $\mathrm{T}_{4}$ (Application of IBA @ $50 \mathrm{ppm})$ treatment with variety Golden Acre $\left(\mathrm{T}_{4} \mathrm{~V}_{1}\right)$ was found significant.

KEY WORDS : Economic, Auxins, Yield, Cabbage

HOW TO CITE THIS PAPER : Kushwah, J.K., Deo, Chandra, Kumar, Vijay, Verma, R.K. and Kumar, Rajesh (2015). Effect of auxin concentrations on yield and economics of the crop production of cabbage (Brassica oleracea var. capitata L.). Internat. Res. J. Agric. Eco. \& Stat., 6 (1) : 132-135. 